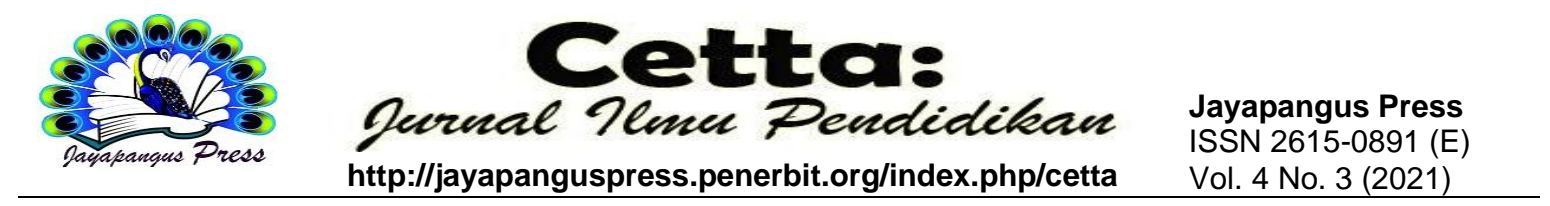

\title{
Penggunaan Metode Problem Based Learning Dalam Meningkatkan Keaktifan Belajar Siswa Pada Kelas XI IPS 1
}

\section{Iwan Ramadhan}

Fakultas Keguruan dan Ilmu Pendidikan Universitas Tanjungpura iwan.ramadhan@untan.ac.id

\begin{tabular}{l}
\hline Keywords: \\
\hline Use, Problem \\
Based Learning \\
(PBL), active \\
learning. \\
\hline
\end{tabular}

Kata Kunci:

Penggunaan, Problem Based

Learning (PBL), keaktifan belajar.

\begin{abstract}
The learning process has the use of various learning methods, one of which is the Problem Based Learning (PBL) method. The research problem is how the planning steps and the process of implementing the PBL method in increasing student learning activity in class XI IPS 1 at SMA Mujahidin Pontianak. The purpose of this study was to obtain information and clarity regarding the planning steps and the process of applying the $P B L$ method as well as student learning acquisition in increasing student learning activity in class XI IPS 1 at SMA Mujahidin Pontianak. The research method used is a qualitative approach method. Active learning in class XI students at SMA Mujahidin Pontianak includes three domains, namely; Cognitive skills, namely initiative, activeness, cooperation, and accuracy in answering students have scores above the PP-completeness of 83\%. Affective; acceptance, participation, assessment/ determination of character, and organization whose percentage is above $83.33 \%$ completeness. Psychomotor; children's movements include perception, readiness, guided movements and complex movements based on observations showed that, children followed well by $78.34 \%$..
\end{abstract}


ketepatan menjawab siswa mempunyai nilai di atas ketuntasanPP sebesar $83 \%$. Afektif; penerimaan, partisipasi, penilaian/ penentuan sifat, dan organisasi yang persentasenya di atas ketuntasan 83,33\%. Psikomotor; gerakan-gerakan anak meliputi persepsi, kesiapan, gerakan terbimbing dan gerakan yang kompleks berdasarkan pengamatan menunjukkan bahwa, anak mengikuti dengan baik sebesar 78,34\%.

\section{Pendahuluan}

Dalam menjalankan kehidupan sehari-hari, sebagai makhluk sosial bahwasanya setiap individu memiliki berbagai masalah yang harus dihadapi (Fitriya, 2019) dan masalah tersebut harus diselesaikan menggunakan cara yang baik sehingga dapat dijadikan sebagai suatu pembelajaran, sama halnya pada perihal pendidikan. Masalah yang dihadapi dunia pendidikan di antaranya sering kali membicarakan tentang proses pembelajaran yang terbilang sangat kurang, dan hal ini menyebabkan problematika pendidikan yang ada di Indonesia menjadi kompleks (Afifah, 2015). Pada pembelajaran berlangsung, siswa selalu diarahkan untuk menghafal fakta dan konsep dari informasi yang disampaikan guru. Padahal dengan adanya suatu pendidikan, maka peserta didik dapat menyelesaikan suatu permasalahannya, sebab pendidikan ini juga mengajarkan tentang bagaimana caranya untuk menghadapi suatu permasalahan bukan hanya mengenai fakta dan konsep saja di dalam kehidupannya. Selain itu pengetahuan yang terus berevolusi tentang tumbuh dan berkembang seiring dengan pengalaman baru dalam kegiatan pembelajaran. Adanya pengetahuan yang semakin berkembang maka akan mendapatkan pengalaman baru pula dan dengan adanya pengalaman baru maka membuat mereka untuk memodifikasi serta mengkonstruksi pengetahuan ketika peserta didik mengetahui adanya permasalahan di lingkungan mereka. Oleh karena itu, sudah semestinya pada penyusunan materi ajar juga menggunakan pembelajaran yang berbasis pada masalah atau dapat dikatakan pembelajaran yang berkaitan dengan permasalahan. Dalam hal ini, guru perlu memiliki strategi serta konsep dalam pembelajaran sehingga peserta didik dapat belajar secara efektif serta efisien, hingga tujuan pembelajaran yang diharapkan dapat dicapai dengan baik (Nasution, 2017), serta kegiatan dan langkah dalam pembelajaran akan lebih terarah dan jelas (Pane \& Dasopang, 2017).

Berdasarkan survey awal yang telah dilakukan, maka dapat diperoleh hasil data terkait dengan nilai rata-rata ulangan harian semester ganjil tahun pelajaran 2011/2012 siswa kelas XI SMA Mujahidin Pontianak hanya sebesar 64,00. Perolehan nilai ini 
terbilang masih sangat jauh dari nilai standar yang seharusnya siswa raih pada ketuntasan belajar siswa untuk mata pelajaran Sosiologi yakni sebesar 75.00. Dengan kondisi demikian, mengisyaratkan bahwa hasil belajar siswa yang rendah untuk pelajaran Sosiologi perlu diatasi dengan berbagai upaya. Berkaitan dengan hal tersebt, beberapa penyebab rendahnya hasil belajar Sosiologi atau ketidaktuntasan siswa adalah faktor internal dan eksternal dari siswa itu sendiri. Faktor internal diantaranya adalah sikap masa bodoh, kurang termotivasi dan tidak fokusnya siswa terhadap materi pelajaran ketika proses belajar mengajar berlangsung. Sedangkan pada faktor eksternal dapat dilihat dari fasilitas-fasilitas yang diberikan pada proses belajar mengajar seperti kurikulum pembelajaran, sumber belajar serta keahlian guru dalam mengajari siswa. Kurangnya pengetahuan guru dalam penggunaaan metode pembelajaran juga berpengaruh pada keberhasilan siswa, salah satunya metode konvensional.

Metode yaitu suatu langkah yang berfungsi sebagai alat dalam mencapai suatu tujuan (Wedi, 2016). Metode konvensional yang digunakan dalam pelajaran Sosiologi menyebabkan siswa terpaku mendengarkan, situasi pelajaran yang mengarhkan dalam "learning to know" serta dalam menyampaikan suatu permasalahan yang lebih kepada hal akademik (book oriented) tidaklah merujuk kepada permasalahan kontekstual yang terkait dengan kehidupan nyata peserta didik. Hal ini tampak pada rendahnya kemampuan anak dalam mengemukakan pendapat dan menjawab soal-soal yang bersifat nalar, anak cenderung hanya menghafal. Pembelajaran seperti itu juga tidak mengoptimalkan atau tidak menggali secara maksimal potensi siswa karena siswa sudah merasa aman (cukup) dengan berbagai informasi yang disampaikan guru. Sebaliknya pembelajaran berbasis masalah (problem based learning) menuntun peserta didik agar bisa merasakan keresahan karena kesenjangan yang terjadi di lingkungan mereka akibatnya dirasakan ada sesuatu yang kurang pada diri mereka sehingga berupaya untuk mencari solusi dari masalah tersebut.

Hal tersebut menyiratkan bahwa proses pembelajaran merupakan keterampilan yang ditampilkan dengan cara yang mudah dengan dilihat pada aktif atau tidaknya siswa dalam menanggapi perihal peristiwa yang terjadi di lingkungannya diwujudkan (Tobrani \& Mustofa, 2011), sehingga hal tersebut mengandung makna teori belajar konstruktivisme. Konstruktivisme berakar pada pragmatisme artinya pengehatuan yang tidak bisa dipisah untuk dijadikan sebuah fakta yang terpisah akan tetapi pengetahuan merupakan cerminan dari sebuah keterampilan yang diterapkan. Kontruktivistik 
meninggalkan pola keseragaman dan memunculkan pola keberagaman, justru dengan keberagaman akan menjadi kekuatan yang luar biasa, demikian juga warna keberagaman menjadi indah dan tidak membosankan (Yamin, 2011). Dalam mengembangkan pembelajaran konstruktivisme, terdapat berbagai macam model dalam menjalankan proses pembelajaran tersebut, salah satunya model pembelajaran berbasis masalah.

Pembelajaran berbasis masalah (Problem Based Learning) ataupun yang sering disebut dengan PBL adalah suatu model pembelajaran yang menyajikan suatu kegiatan pembelajaran yang inovatiif kepada peserta didik dan diharapkan dapat meningkatkan keaktifan seorang peserta didik (Aman, 2016). Pembelajaran ini berfokus kepada peserta didik dalam meningkatkan prestasi dan motivasi belajar peserta didik (Moningka, 2015). Model pembelajaran yang bersifat inovatif inilah yang diharapkan dapat membuat siswa menjadi harus bersikap aktif sehingga siswa dapat melakukan kerjasama yang baik antar sesama temannya untuk menyelesaikan dan mencari solusi dalam permasalahan yang ada di kehidupan nyata (Yamin, 2011), sehingga setiap peserta didik dituntut agar dapat berpikir kritis serta menempatkan peserta didik ke dalam objek pembelajaran yang utuh (Aji \& Mediatati, 2021). Dalam hal ini, masalah yang dijadikan suatu pokok utama dalam proses pembelajaran diharapkan peserta didik dapat menyelesaikannya dengan cara berkelompok sehingga antar siswa dapat berbagi pengalaman baru ketika menyelesaikan tugas kelompoknya dan siswa juga bisa belajar mengenai caranya bekerja sama di dalam kelompok, sehingga dari konsep tersebut, bahwa kemampuan berpikir kritis dijadikan sebagai hal yang terpenting dalam pelaksanaan kegiatan pembelajaran (H. D. Cahyani, Hadiyanti, \& Saptoro, 2021). PBL juga merupakan salah satu konsep dimana kegiatan pembelajaran dilakukan dengan mempelajari setiap permasalahan nyata yang terdapat pada kehidupan sehari-hari (Maryati, 2018), serta berprinsip kepada permasalahan yang merupakan titik awal dalam peserta didik mendapatkan suatu pengetahuan serta pengalaman yang baru (Komalasari, 2010). Hal ini akan memicu daya pikir peserta didik menjadi lebih kritis dan peserta didik memiliki keinginan dalam memecahkan suatu permasalahan yang disajikan oleh guru (Camelia \& Maknun, 2021), serta peserta didik dapat mengembangkan keterampilan dalam menalar dan mampu merumuskan setiap ide yang ada dalam diri peserta didik tersebut (Nafiah, 2014). Dari hal tersebut, tujuan penelitian ini dilakukan untuk mendapatkan informasi dan kejelasan terkait langkahlangkah perencanaan dan proses penerapan metode PBL dalam meningkatkan keaktifan belajar peserta didik di kelas XI IPS 1 di SMA Mujahidin Pontianak. 


\section{Metode}

Metode penelitian yang digunakan dalam penelitian ini yaitu jenis penelitian dengan pendekatan kualitatif, bahwa strategi penelitian ini merupakan strategi yang memiliki sejumlah sifat dari serangkaian asumsi yang saling berhubungan yang bersifat khas (Alwasilah, 2008). Subjek penelitian ini adalah guru mata pelajaran Sosiologi dan siswa kelas XI IPS 1 SMA Mujahidin Pontianak sebagai obyeknya.

Teknik pengumpulan data yang digunakan adalah observasi, wawancara mendalam, dan dokumentasi. Dalam perihal keabsahan data juga harus diperhatikan, terdapat kriteria pemeriksaan data dengan cara kriteria derajar kepercayaan (credibility). Dengan adanya kredibilitas maka hasil penelitian dapat selalu terjaga, terdapat beberapa cara dalam menjaga kredibiltas hasil penelitian seperti melakukan validisai triangulasi, member check, dan pendapat para ahli. Analisis dilakukan melalui tiga alur kegiatan yaitu reduksi data, penyajian data dan penarikan kesimpulan, dimana bahwa terdapat tiga alur dalam menganalisis data yaitu reduksi data, penyajian data serta penarikan kesimpulan/verifikasi (Miles \& Huberman, 1992).

\section{Hasil dan Pembahasan}

Dalam pelaksanaan pembelajaran berdasarkan masalah atau problem based learning (PBL) ini menunjukkan hasil-hasil sebagai berikut:

1. Proses pemecahan masalah (melakukan refleksi)

Pemecahan masalah dimaksudkan disini sebagai suatu kegiatan atau proses yang sudah direncanakan dan perlu diimplementasikan agar mendapatkan suatu jalan keluar dari suatu masalah yang mungkin tidak diselesaikan secara instan (H. Cahyani \& Setyawati, 2017). Dalam memecahkan masalah terutama dalam proses pembelajaran, perlu ditentukan apa saja yang sudah diketahui dan memperoleh gambaran umum dalam penyelesaiannya, serta mempunyai tujuan yang jelas (Akhsani \& Jaelani, 2018). Pada kegiatan pembelajaran, sebelum mengakhiri pembelajaran, peserta didik diajak untuk merefleksi kegiatan pembelajaran yang telah mereka lakukan. Bagaimana tahapan proses pembelajaran dari awal merumuskan masalah, sampai mempresentasikan laporan yang mereka buat, sehingga memantapkan penguasaan materi pelajaran. Hal ini menuntut peserta didik sehingga dapat memadukan setiap sistem mulai dari kognitif, metakognitif, hingga pengaturan 
diri dan strategi-strategi lainnya (Sari, Maidiyah, \& Anwar, 2019), serta mengetahui setiap kendala dari proses pembelajaran yang dilaksanakan agar dapat menemukan alternatif solusi dalam kegiatan pembelajaran selanjutnya (Amalia \& Putra, 2019).

2. Pemerolehan belajar

Dalam pemerolehan belajar, hal ini berkaitan dengan hasil belajar yang diperoleh oleh peserta didik. Penilaian hasil belajar diterapkan kepada peserta didik dalam mengetahui dan memperoleh apakah peserta didik tersebut memiliki kompeten atau tidak memiliki kompeten di dalam menguasai suatu kemampuannya di dalam pembelajaran (Nurtanto \& Sofyan, 2015). Pemerolehan hasil belajar meliputi ranah kognitif, afektif dan fsikomotorik, dan ketiga ranah tersebut tidak dapat dipisahkan antara satu dengan yang lain secara mudah (Hasyim, Nur, \& Buditjahjanto, 2013). Pada ranah kognitif aktivitas siswa menunjukkan hasil bahwa inisiatif siswa rata-rata bernilai 18,83 atau 75,33\% dari nilai maksimal 25, pada aspek keaktifan rata-rata nilai 20,67 atau $82,68 \%$, kerja sama rata-rata nilai 20,67 atau $90,86 \%$ dan aspek presentasi 19,5 atau 78\%. Dari hasil keseluruhan rata-rata nilai yang diperoleh kelompok sebesar 81,66 yang berarti sebesar $82 \%$ pembulatan.

Dari hasil prosentasi yang diperoleh, ternyata pembelajaran Sosiologi dengan metode problem based learning (PBL) membuat peserta didik dapat bekerja sama dengan teman-temannya, hal itu ditunjukkan oleh tingginya prosentase pada aspek ini yaitu sebesar 90,86\%. Kerja sama juga ditunjukkan dengan saling berkomunikasi, saling bertanya. Komunikasi awal dilakukan dengan teman anggota kelompoknya pada saat mengerjakan tugas. Intensifnya komunikasi dan tanya jawab yang dilakukan sesama anggota kelompok menumbuhkan keberanian anak untuk bertanya terhadap guru, apalagi kalau guru yang mendatangi atau mendekati posisi kelompok. Di sini terjadi perubahan sikap terhadap anak karena dari tanya jawab untuk bertukar pikiran dengan temannya membuat siswa tersebut menjadi lebih aktif dalam pembelajaran. Keadaan tersebut dapat digambarkan seperti metode tanya jawab yang memiliki kekuatan tersebut (Sumantri \& Permana, 1999). Oleh sebab itu keberanian anak untuk bertanya terlihat mengalami peningkatan yang berarti juga meningkatkan keberanian untuk mengungkapkan pendapat. Keaktifan anak dalam pembelajaran ternyata bukan hanya menumbuhkan keberanian bertanya, dalam hal ini mencakup aspek fisik serta mental (Hotijah, 2020), tetapi peserta didik juga kelihatan lebih berani untuk mempresentasikan hasil kerja 
kelompoknya walaupun pada awalnya merasakan gugup atau berdebar-debar tapi akhirnya biasa saja (Sanjaya, 2009).

Dalam mempresentasikan atau melaporkan hasil kerja kelompok, siswa juga tidak terlepas dari adanya tanya jawab. Ini berarti keterampilan anak dalam mengungkapkan pendapat mengalami peningkatan dapat dilihat dari bagaimana cara anak bertanya atau keterampilan bertanya. Dengan sering bertanya, selain dapat memotivasi anak terlibat dalam aktivitas belajar, juga merangsang serta meningkatkan kemampuan berfikir siswa, hal ini dapat dimaksud bahwa keterampilan bertanya yang terarah pada tujuan tertentu. Adanya keterbatasan waktu mengakibatkan tidak semua kelompok bisa mempresentasikan hasil laporannya, itulah yang menyebabkan nilai presentasi rataratanya kecil yaitu $78 \%$ dan inisiatif $75,33 \%$ tetapi masih di atas kriteria ketuntasaan minimal (KKM).

Hasil penilaian proses, menunjukkan bahwa anak sudah dapat menyelesaikan tugasnya dengan baik. Hal itu ditunjukkan dengan perolehan nilai esensi jawaban siswa yang mencapai rata-rata 60,83 dari skor maksimal 75 atau $81 \%$. Nilai terendah terdapat pada aspek ketepatan waktu hanya $73 \%$ berarti masih di bawah target yang diharapkan. Dalam hal ini memang anak merasakan waktu yang diberikan tidak cukup untuk mengarjakan tugas yang diberikan karena ada beberapa tahapan yang harus dilalui tidak seperti pem-belajaran biasa, diantaranya adalah anak harus merumuskan masalah terlebih dahulu, baru menjawab dan melaporkannya secara tertulis. Jadi untuk keterampilan memecahkan masalah sebagian besar siswa mengaku mampu melakukannya atau menyelesaikannya, karena memang serius dan antusias mengikuti langkah-langkah pembelajaran dari merumuskan masalah, mengumpulkan fakta/informasi, dalam penyelidikan, membuat laporan sampai pada tahap melaporkan hasil kerja mereka. Pemecahan masalah juga termasuk ke dalam sebuah keterampilan seseorang, di mana pada proses pemecahan masalah seseorang juga menggunakan pikirannya untuk memahami apa yang telah terjadi sehingga seseorang akan mudah untuk memecahkan suatu permasalahan dengan proses berfikirnya selain itu, seseorang juga akan mencari beberapa bukti atau dapat dikatakan suatu fakta yang terjadi sehingga fakta tersebut dapat dipelajarinya untuk proses pemecahan permasalahannya (Ahmadi \& Amri, 2011).

Untuk hasil pengamatan diskusi ranah afektif menunjukkan, bahwa aspek penerimaan yaitu kesediaan siswa untuk memperhatikan penjelasan guru memperoleh nilai rata-rata tertinggi 4,83 atau $96,67 \%$. Nilai yang sangat baik menunjukkan siswa 
sangat tertarik dengan media yang ditayangkan. Pada dasarnya, adanya media dapat meningkaykan minat siswa dalam proses belajarnya. Media dan proses pembelajaran merupakan proses yang saling berkaitan dimana keduanya sama-sama penting untuk meningkatkan minat belajar siswa terhadap materi pelajaran dan siswa juga tidak akan merasa bosan karena pembelajarannya sangat bervariasi dengan adanya kontribusi dari media (Sanjaya, 2009).

Aspek partisipasi juga menunjukan nilai yang baik yaitu 4,00 atau $80,00 \%$, berarti siswa bisa berpartisipasi secara aktif dalam pembelajaran dan menyukai pembelajaran dengan berkelompok atau diskusi kelompok. Memang seperti yang dinyatakan oleh beberapa siswa, langkah yang paling seru adalah pada saat mereka menyelesaikan tugas dan melakukan diskusi dengan teman sekelompoknya. Mereka juga merasa lebih nyaman, seru, menyenangkan, lebih bersemangat dan tidak tegang dengan pembelajaran berkelompok. Pada aspek penilaian atau penentuan sikap yaitu kemampuan siswa untuk memberikan penilaian yang dinyatakan dengan tingkah laku, misalnya rasa senang dapat dilihat dari keseriusan dan antusias siswa dalam pembelajaran. Hasil belajar dari sikap merupakan kapabilitas-kapabilitas yang mendasari berbagai jenis unjuk kerja, buah dari belajar juga berupa terbentuknya keadaan internal yang yang mempengaruhi pilihan individu akan tindakan pribadi, apabila sikap belajar tersebut dilakukan dengan positif, maka peserta didik tersebut cenderung akan mengikuti proses pembelajaran dan proses belajar dengan baik (Martias, Darman, \& Rati, 2015).

Dilihat dari tindakan individu dan semangat siswa dalam pembelajaran dan pemerolehan nilai rata-rata kelompok sebesar 4,00 atau 80,00\%. menurut hemat peneliti dari sikap siswa, sehingga bisa dikatakan bahwa mereka menyenangi pembelajaran dengan metode problem based learning. Organisasi merupakan aspek dalam melihat kemampuan siswa menyelesaikan konflik atau masalah kelompok dalam menyelesaikan tugas belajar siswa. Pada aspek ini menuntut kesungguhan atau keseriusan yang tinggi, tapi secara umum siswa bisa melakukannya dengan baik. Hal itu terlihat dari pemerolehan nilai walaupun terkecil yaitu 3,83 atau $76,67 \%$ tapi masih di atas KKM. Untuk hasil pengamatan diskusi (psikomotor), menunjukkan bahwa aspek psikomotor gerak persepsi anak berupa kemampuan merespon pertanyaan yang diajukan guru dan aspek kesiapan yaitu bagaimana anak memposisikan/menempatkan diri pada kelompoknya ketika guru memberikan penjelasan, mendapatkan nilai yang baik dengan rata-rata 4,00 atau 80,00\%. Hal ini menjadi modal awal sebuah pembelajaran karena sikap siswa sudah masuk di 
dalam kondisi belajar. Di sini peserta didik sudah memilih memfokuskan diri dan pikirannya untuk belajar, berarti anak dapat menjaga ketertiban kelas selama proses pembelajaran. Pada aspek gerakan terbimbing yatu bagaimana siswa bisa duduk sesuai dengan pembagian kelompok pada saat guru melakukan eksplorasi dan mengerjakan tugas mencapai nilai cukup yaitu sebesar 3,83 atau 76,67\% siswa siap melakukan pembelajaran berkelompok (cooperative learning) yang menjadi ciri khas dari pembelajaran berbasis masalah (PBL). Dalam pembelajaran kelompok maka setiap siswa akan bekerjasama untuk menyampaikan pendapatnya masing-masing sehingga siswa akan saling menerima pendapat dari semua kelompok. Adanya perasaan saling memberikan manfaat membuat siswa bisa bekerja sama dengan baik, mereka bisa saling mengisi, berbagi dan saling mendukung. Aspek gerakan yang kompleks menunjukkan nilai baik yaitu 3,83 atau $76,67 \%$, ini berarti siswa bisa mengikuti langkah-langkah pembelajaran dan melaksanakan tugas yang diberikan guru.

Jadi secara umum kemampuan psikmotor anak pada saat pembelajaran sudah cukup baik dengan rata-rata pemerolehan nilai sebesar 3,92 atau 78,30\% berarti di atas ketuntasan. Sebelum pembelajaran ditutup, siswa diberikan soal evaluasi untuk melihat ketercapaian pemahaman terhadap materi pembelajaran. Berdasarkan hasil yang diperoleh maka dapat dikelompokkan melalui tiga kategori nilai yaitu tinggi, sedang dan rendah. Untuk kategori tinggi ada 14 siswa atau 46,67\% dengan pemerolehan nilai 85 ke atas, kategori sedang 11 orang atau 36,67\% dengan pemerolehan nilai antara 75-84 dan sebanyak 5 siswa terletak pada kategori rendah masih di bawah ketuntasan. Berdasarkan nilai yang diperoleh sebanyak 25 atau 83,34\% siswa mencapai ketuntasan sedangkan 5 atau 16,67\% siswa di bawah ketuntasan, akan tetapi jika dilihat pada keseluruhan nilai rata-rata kelas sebesar 82,83 . Siswa yang memperoleh nilai di atas ketuntasan mempunyai motivasi yang tinggi (antusias) dan aktif selama proses pembelajaran belajar (Ahmadi \& Amri, 2011).

\section{Kesimpulan}

Hasil dari penelitian yang dilakukan bahwa pembelajaran berbasis masalah (PBL) cukup efektif di dalam mengembangkan kemampuan peserta didik serta dalam pembelajaran ini, peserta didik juga memiliki nilai-nilai karakter yang terdapat dalam kegiatan pembelajaran seperti nilai tanggung jawab, kerjasama, demokrasi, dan lain-lain, serta peserta didik dapat berpartisipasi aktif dalam mengemukakan pendapat dan 
masukkannya terkait isi pembelajaran yang dilakukan oleh peserta didik tersebut. Saran untuk pembelajaran berbasis masalah, guru diharapkan dapat memahami dengan baik apa saja yang perlu dipersiapkan dalam menyusun rencana pembelajaran, termasuk juga kepada peserta didik, agar lebih aktif, serta dapat memahami setiap pembelajaran yang disampaikan oleh pendidik atau guru. Hasil dari penelitian yang dilakukan bahwa pembelajaran berbasis masalah (PBL) cukup efektif di dalam mengembangkan kemampuan peserta didik serta dalam pembelajaran ini, peserta didik juga memiliki nilainilai karakter yang terdapat dalam kegiatan pembelajaran seperti nilai tanggung jawab, kerjasama, demokrasi, dan lain-lain, serta peserta didik dapat berpartisipasi aktif dalam mengemukakan pendapat dan masukkannya terkait isi pembelajaran yang dilakukan oleh peserta didik tersebut. Saran untuk pembelajaran berbasis masalah, guru diharapkan dapat memahami dengan baik apa saja yang perlu dipersiapkan dalam menyusun rencana pembelajaran, termasuk juga kepada peserta didik, agar lebih aktif, serta dapat memahami setiap pembelajaran yang disampaikan oleh pendidik atau guru.

\section{Daftar Pustaka}

Afifah, N. (2015). Problematika pendidikan di Indonesia (telaah dari aspek pembelajaran). Elementary: Jurnal Ilmiah Pendidikan Dasar, 1(1), 41-47.

Ahmadi, I. K., \& Amri, S. (2011). Mengembangkan pembelajaran IPS terpadu (analisis kritis tentang metode, strategi, evaluasi dan media pembelajaran bidang studi sejarah, geografi, ekonomi, sosiologi, antropologi dan isu pembelajaran IPS terpadu. Jakarta: Prestasi Pustakarya.

Aji, S. B., \& Mediatati, N. (2021). Penerapan problem based learning untuk meningkatkan hasil belajar IPA di sekolah dasar. Edukatif: Jurnal Ilmu Pendidikan, 3(5), 2734-2780.

Akhsani, L., \& Jaelani, A. (2018). Peningkatan kemampuan pemecahan masalah matematis mahasiswa melalui metode snow ball throwing pada mata kuliah teori Graf. Kontinu: Jurnal Penelitian Didaktik Matematika, 2(2), 48-59. https://doi.org/10.30659/kontinu.2.1.58-71

Alwasilah, A. C. (2008). Pokoknya Kualitatif (Dasar-Dasar Merancang dan Melakukan Penelitian Kualitatif). Jakarta: PT Dunia Pustaka Jaya.

Amalia, R., \& Putra, E. D. (2019). Refleksi pembelajaran: modifikasi problem based learning untuk mendeskripsikan kemampuan berpikir kritis siswa. Jurnal 
Emasains, $\quad 8(1), \quad$ 1-7. $\quad$ Retrieved from https://ojs.mahadewa.ac.id/index.php/emasains/article/view/264

Aman, K. (2016). Penerapan model Problem Based Learning dalam pembelajaran sejarah untuk meningkatkan motivasi dan prestasi belajar siswa kelas XI IPS 1 SMAN 1 Butar Sulawesi Tengah. Istoria: Jurnal Pendidikan Dan Sejarah, 12(1), $28-46$.

Cahyani, H. D., Hadiyanti, A. H. D., \& Saptoro, A. (2021). Peningkatan sikap kedisiplinan dan kemampuan berpikir kritis siswa dengan penerapan model pembelajaran problem based learning. Edukatif: Jurnal Ilmu Pendidikan, 3(3), 919-927.

Cahyani, H., \& Setyawati, R. W. (2017). Pentingnya peningkatan kemampuan pemecahan masalah melalui PBL untuk mempersiapkan generasi unggul menghadapi MEA. PRISMA: Prosiding Seminar Nasional Matematika, 151-160. Retrieved from https://journal.unnes.ac.id/sju/index.php/prisma/article/view/21635

Camelia, C., \& Maknun, L. (2021). Implementasi problem based learning (PBL) dalam pembelajaran jarak jauh di MI Al-Mursyidiyyah selama masa pandemi. Elementar (Elementary of Tarbiyah): Jurnal Pendidikan Dasar, 1(1), 22-37.

Fitriya, A. (2019). Upaya pemecahan masalah dengan bantuan bimbingan dan konseling. Journal of Chemical Information and Modeling, 10(1).

Hasyim, Z., Nur, M., \& Buditjahjanto, I. G. P. A. (2013). Pengembangan perangkat pembelajaran memasang instalasi penerangan listrik bangunan sederhana pada materi memasang instalasi penerangan di luar permukaan menggunakan model pembelajaran langsung. Jurnal Pendidikan Vokasi: Teori Dan Praktek, 1(1), 1731.

Hotijah, S. (2020). Hubungan keaktifan bertanya dengan hasil belajar pada mata pelajaran ekonomi kelas XI IPS SMA. Jurnal Pendidikan Dan Pembelajaran Khatulistiwa, 9(3), 1-9. 10 Retrieved https://jurnal.untan.ac.id/index.php/jpdpb/article/view/39916

Komalasari, K. (2010). Pembelajaran Kontekstual Konsep dan Aplikasi. Bandung: Refika Arditama.

Martias, Darman, \& Rati, A. (2015). Hubungan sikap belajar dengan hasil belajar mata pelajaran alat ukur kelas $\mathrm{X}$ teknik kendaraan ringan di SMK Negeri 1 Padang. Automotive Engineering Education Journals, 4(4), 1-10. Retrieved from 
http://ejournal.unp.ac.id/students/index.php/poto/article/view/1950

Maryati, I. (2018). Penerapan model pembelajaran berbasis masalah pada materi pola bilangan di kelas VII sekolah menengah pertama. Jurnal Mosharafa, 7(1), 63-74.

Miles, M. B., \& Huberman, A. M. (1992). Analisis Data Kualitatif (Buku Sumber Tentang Metode-Metode Baru). Jakarta: Universitas Indonesia Press.

Moningka, C. (2015). Problem based learning dengan metode jigsaw: uji coba pada mahasiswa psikologi Universitas Bunda Mulia. Jurnal Psibernetika, 8(1), 35-47.

Nafiah, Y. N. (2014). Penerapan model problem-based learning untuk meningkatkan keterampilan berpikir kritis dan hasil belajar siswa. Jurnal Pendidikan Vokasi, $4(1), 125-143$.

Nasution, M. K. (2017). Penggunaan metode pembelajaran dalam peningkatan hasil belajar siswa. Sutdia Didaktika: Jurnal Ilmiah Bidang Pendidikan, 11(1), 9-16.

Nurtanto, M., \& Sofyan, H. (2015). Implementasi problem-based learning untuk meningkatkan hasil belajar kognitif, psikomotor, dan afektif siswa di SMK. Jurnal Pendidikan Vokasi, 5(3), 352-364. https://doi.org/10.21831/jpv.v5i3.6489

Pane, A., \& Dasopang, M. D. (2017). Belajar dan pembelajaran. Fitrah: Jurnal Kajian Ilmu-Ilmu Keislaman, 3(2), 333-352.

Sanjaya, W. (2009). Pembelajaran Berorientasi Standar Pendidikan. Bandung: Pernanda Media Group.

Sari, L., Maidiyah, E., \& Anwar. (2019). Proses pemecahan masalah matematis siswa SMP materi bentuk Aljabar melalui model Problem Based Learning. Jurnal Peluang, 7(2), 77-84. https://doi.org/10.24815/jp.v7i2.15099

Sumantri, M., \& Permana, J. (1999). Strategi Belajar Mengajar. Departemen Pendidikan dan Kebudayaan Direktorat Jenderal Pendidikan Tinggi Proyek Pendidikan Guru Sekolah Dasar (Primary School Teacher Development Project).

Tobrani, M., \& Mustofa, A. (2011). Belajar dan Pembelajaran. Yogyakarta: Ar-Ruzz Media.

Wedi, A. (2016). Konsep dan masalah penerapan metode pembelajaran: upaya peningkatan mutu pembelajaran melalui konsistensi teoretis-praktis penggunaan metode pembelajaran. Edcomtech: Jurnal Kajian Teknologi Pendidikan, 1(1), 2128.

Yamin, M. (2011). Paradigma Baru Pembelajaran. Jakarta: Gaung Persada Pers. 